\title{
DOES COMPETITION IMPROVE PERFORMANCE? EVI- DENCE FROM THE CZECH MANUFACTURING INDUSTRIES
}

\author{
Andrei MEDVEDEV, Alena ZEMPLINEROVÁ*
}

\begin{abstract}
The paper investigates both the impact of domestic and import competition on performance of manufacturing industries in the Czech Republic in 1998 - 2002. Using panel data we found a strong increasing non-linear (diminishing) relationship between performance of manufacturing industries and domestic competition measured by the Herfindahl-Hirschman Index. Import competition measured by an import penetration ratio is negatively related to performance of Czech industries, while foreign direct investments are positively correlated with performance.
\end{abstract}

Keywords: competition, competitiveness, concentration, growth, transition, Czech Republic

JEL classification: D24, L60, P23

\section{Introduction}

For the last 15 years Czech enterprises have been facing significant changes in the economy, i.e. in the governance and competitive environments. The transition of formerly centrally planned economies goes hand in hand with changes in industrial structure. On the one hand transition it is a historically unique situation which has brought about a special set of changes. On the other hand, the intensity of these changes provides a laboratory for general trends, which would not be easily seen in ordinary circumstances and which are therefore interesting to explore. One of the main characteristics of the centrally planned economy in the Czech Republic as well as in all other ex-communists countries was a high concentration in industries especially in manufacturing. Before 1989, the supply of most products and services had been controlled by one or a few state enterprises and most industries were isolated from the world markets. Between 1989 and 1993, the number of enterprises incre-

*) CERGE-NHÚ AV ČR, Politických vězňů 7, CZ 11121 - Prague 1 (e-mail: andrei.medvedev@cergeei.cz; alena.zemplinerova@ cerge-ei.cz).

$\left.{ }^{* \star}\right)$ The analysis has been carried out within the 5th Framework Programme - project "Changes in Industrial Competitiveness as a Factor of Integration," supported by the European Commission. The authors are, however, solely responsible for any use that might be made of data appearing therein.

${ }^{\star * \star}$ ) We thank Alexandru Chirmiciu, Mary O’Donell, Iraj Hashi, Randall Filer, Valeri Nikolaev, and Štěpán Jurajda for valuable comments and suggestions. 
ased significantly in all industries due to both spontaneous break-ups of large enterprises as well as due to numerous new starts-ups. Therefore, deconcentration occurred despite the fact that between 1989 and 1993 manufacturing output declined by 38 per cent in real terms. At the same time due to the liberalization of foreign trade, import penetration in total manufacturing increased to 36 per cent as by 1993 (see Zemplinerová, Stibal, 1995).

The economy started to grow in 1994: The growth, however, has been highly uneven across industries. As a consequence the structure of manufacturing started to change during the period 1993 - 1997 (see Havlik, 2000). Moreover, import penetration continued to increase reaching 60 per cent in 1997 (see Zemplinerová, 2000). In addition foreign direct investment $(F D I)$ inflows increased considerably over this period of time and the share of enterprises in foreign ownership in total manufacturing output reached 23 per cent by 1997. The period $1998-2002$ is the period of second transformation recession and subsequent recovery. During this period major banks have been privatized, numerous mergers occurred as new entries via green field investment. In addition, the bankruptcy was much more frequent and allowed for numerous exits from the declining markets (see Lízal, 2001). This paper attempts to measure both the levels of market concentrations and import competition and to relate the intensity of competition to the performance of these markets during $1998-2002$.

There are numerous empirical investigations of the influence of competition on industry's and firm's performance, however, the results are ambiguous. In many studies of developed countries a positive correlation between the degree of market competition and the growth rate of different measures of performance has been recorded. For example, Nickell (1996) analyzes the impact of competition on both the level and the growth of total factor productivity (TFP) in the UK. He found that competition measured by increased numbers of competitors or by lower levels of rents, was associated with a significantly higher rate of total factor productivity growth. Geroski (1990) used panel data to show that concentration reduces the innovation rate and the productivity growth. Vining and Boardman (1992) found that market competition had a positive influence on performance for Canadian companies.

There exist studies that have investigated the relationship between the performance and concentration intensity measured by the Herfindahl-Hirschman Index ${ }^{1)}$ $(H H I)$ in transition countries. ${ }^{2)}$ For example, Halpern and Korosi (2000) found a positive relationship between concentration and performance in Hungary; Brown and Earle (2000) reported a positive relationship between the HHI and TFP for Russia. Angelucci et al. (2001) found that domestic competitive pressure was associated with better firm performance in Poland, while increased import competition was associated with lower total factor productivity in Romania and Bulgaria. However, most of the studies focused on the enterprise level data. One of the advantages of enterprise level data is that it can capture such performance related effects as ownership structure. For example, Hanousek et al. (2004) found that concentrated foreign, but not domestic, ownership improves performance relative to state ownership in the Czech Republic.

1) Herfindahl-Hirschner Index is one of the most used measurements of market concentration and is calculated as the sum of squared market shares of firms in the market, $\sum_{i=1}^{n}\left(\text { share }_{i}\right)^{2}$. The alternative competition measures are the market share of the top four firms in a market (CR4) or the number of firms in a market $(1 / n)$.

2) For a survey of the influence of different measures of competition on performance of enterprises and industries in transition countries see Djakov and Murrell (2002). 
A small number of studies have focused on performance at the industry level rather than at enterprise level. Haskel (1991) used a panel of 81 UK industries over the period 1980 - 1986. He found a positive, although weakly significant, relationship between the degree of market concentration and productivity growth. Chirmiciu (2003) used industry level data from Hungary over the period $1992-1998$. He found a non-linear inverse- $\mathrm{U}$ relationship between the $\mathrm{HHI}$ and the level of total factor productivity, i.e. the middle level of market concentration is related with the highest total factor productivity levels. There exist a study carried out on the enterprise level for the Czech manufacturing that found negative correlation between import competition and enterprises' performance (see Sabrianová et al. 2004). They also report that foreign-owned firms are increasingly displacing domestic firms, due to slower "learning" by domestic firms, higher efficiency of foreign start-ups, and foreigners' acquisitions of more efficient domestic firms in the Czech Republic and Russia.

In our paper we use the industry-level 3-digit NACE data to estimate the relationship between market concentration and the performance of Czech industries in manufacturing. At the same time we assess the relation between import penetration and performance of Czech manufacturing industries. For this purpose we matched import data from the trade statistics on 3-digit level to the industrial enterprises data. The data set consists of a panel of 102 industries over the period of 1998 - 2002 and, therefore, we can control for unobserved heterogeneity across industries. The structure of the paper is as follows. First, we derive the basic model to be estimated. Then we describe the data more in detail, and proceed with the discussion of the obtained results before concluding the article.

\section{Methodology}

The methodology used to analyze the relationship between competition and performance using industrial level data is largely based on Haskel (1991) and Chirmiciu (2003). The standard Cobb-Douglas production function of a firm is given as:

$$
Y_{i}=A_{i} K_{i}^{\alpha} L_{i}^{\beta_{i}}
$$

where $K_{i}$ and $L_{i}$ denote the capital and labour employed by a firm $i$, respectively, and $A_{i}$ is a total factor productivity, which captures the labour and capital efficiencies (or inefficiencies such as excessive labour and obsolete assets) and other unobserved factors of production. The total amount of capital in the industry is $K=\sum_{i=1}^{n} K_{i}=K \sum_{i=1}^{n} k_{i}$, where $k_{i}$ is the share of firm's $i$ 's capital in total. Identically the total employment in the industry is $L=\sum_{i=1}^{n} L_{i}=L \sum_{i=1}^{n} l_{i}$, where $I_{i}$ is the share of firm $i$ in total industry employment. The total output in an industry is the sum of the outputs of each individual firm:

$$
Y=\sum_{i=1}^{n} A_{i} K_{i}^{\alpha_{i}} L_{i}^{\beta_{i}}=\sum_{i=1}^{n} A\left(K_{i} K\right)^{\alpha_{i}}(\mid L)^{\beta_{i}}=\sum_{i=1}^{n} A K^{\alpha_{i}} \mid \beta_{i} K^{\alpha_{i}} L^{\beta_{i}}
$$

Then, the output of an industry can be represented in the following way:

$$
Y=K^{\alpha}\left\lfloor\beta \sum _ { i = 1 } ^ { n } A _ { i } K _ { i } ^ { \alpha i } | _ { i } ^ { \beta _ { i } } K ^ { \alpha i - \alpha } \left\lfloor^{\beta i-\beta}\right.\right.
$$

We can assume that elasticities of output with respect to input factors do not differ a lot across firms in the same industry. In this case, the terms $K^{\alpha_{i}-\alpha}$ and $L^{\beta_{i}-\beta}$ are negligible and can be dropped from the analysis. If we can control for the size of an industry (total capital and labour employed by an industry), then the perfor- 
mance of an industry is determined by the industry wide total factor productivity (the summation term in Formula 3). In its own turn, the industry wide total factor productivity is determined by the shares of the firms in production inputs and differences in TFP across firms. Therefore, we can approximate industry wide TFP with competition within industries (market concentration, competition from abroad, and foreign ownership). Our choice of the dependent variable is the annual industry-wide level of sales. ${ }^{3)}$ This choice is consistent with the fact that the $\mathrm{HHI}$ is calculated based on the volume of sales of enterprises. ${ }^{4)}$ In the paper we would like to assess the relationship between competition and the performance of industries, and look at the effects of different types of competition on the performance of Czech manufacturing industries.

Using a standard transformation procedure the Cobb-Douglas production function can be written in logarithmic form as follows:

$$
\ln Y_{i t}=T F P_{i t}+\alpha \ln K_{i t}+\beta \ln L_{i t}
$$

To control for industry size we include capital as measured by the industry-wide volume of current assets, and labour as measured by the number of employees in an industry. In order to control for functional form of the production function we can use a translog approximation of the unknown production function. It approximates a wide variety of functional forms without imposing many restrictions. The inclusion of this term imposes the constant elasticity on the production function but allows all three types of returns to scale. At the end it adds a new term, $\left(\ln K_{i t}-\ln L_{i t}\right)^{2}$, into the estimated model of the production function (see Chirmiciu, 2003). However, this term appeared to be insignificant under different specifications of the model.

We approximate the intensity of competition in the following way. Domestic competition is measured by the $\mathrm{HHI}$, which measures the concentration in an industry taking into consideration both the number of firms and their size. We might expect the relationship between competition and performance to be non-linear; Schmidt (1997) shows that moderate levels of competition have a positive impact on managerial effort and productivity, whereas very fierce competition reduces profits and, consequently, incentives of managers to improve performance. In order to check this hypothesis we include a squared $\mathrm{HHI}$ term in the model.5)

While the $\mathrm{HHI}$ describes structure of a market and intensity of domestic competition, competition from abroad has two different modes - via import and via foreign direct investment. Hence, foreign competition is captured by the import penetration ratio, which is the share of import in domestic sales, and by the FDI penetration ratio, which is the share of foreign owned enterprises in the $i$-th industry total output. From observing the performance of the best-known and the most successful companies in the Czech Republic we could expect that the best performance is achieved in more concentrated industries with high share of foreign ownership. At the same time most of the studies reported that foreign owned enterprises perform much better

3) Djankov, Murrell (2002) survey different measures of performance of enterprises and industries. Some authors use level variables, others growth rates. It is possible to use volume of sales, or value added, or labour productivity as a performance variable.

4) The $\mathrm{HHI}$ is calculated based on the volume of sales of enterprises which belong to a 3-digit NACE industry.

5) However, the quadratic form is vulnerable to an extreme observations, therefore we double-check the same hypothesis by running regressions with the interaction term between $H H I$ and dummies for low, medium and highly concentrated industries, and checking whether the relationships between $\mathrm{HHI}$ and performance is different for these three types of markets. 
than domestic ones and, consequently, industries with a high share of foreign ownership do better than domestically controlled industries (see Zemplinerová, 1998). Therefore we expect to find support for a widely hold view that the level of foreign direct investment positively affects industry performance.

In order to capture potentially significant unobservable industry specific effects we include the industry dummy $\alpha_{i}$ which controls for unobservable reasons of differences in TFP among industries. At the same time to control for the economy wide shocks, and the movement towards the production frontier by the whole economy during the period of time of interest, we introduce a time trend variable. While the trend variable picks up the effect of growth in all industries during time, we also include an interaction term between the $\mathrm{HHI}$ and trend to test whether more concentrated industries grow faster with time (more concentrated industries picking up more the time effect).

Hence, the full model that we would like to estimate is:

$$
\begin{aligned}
\ln Y_{i t} & =\alpha+\alpha_{i}+\beta_{t} \text { trend }+\delta_{1} \ln K_{i t}+\delta_{2} \ln L_{i t}+ \\
& +\delta_{3}\left(\ln K_{i t}+\ln L_{i t}\right)^{2}+\gamma_{1} H H I_{i t}+\gamma_{2} H H P^{2}+ \\
& +\gamma_{3} \text { trend }^{*} H H I_{i t}+\gamma_{4} \text { impopen }_{i t}+\gamma_{5} F D I_{i t}+\mu_{i}+\varepsilon_{i t}
\end{aligned}
$$

\section{D a t a}

We use two basic data sets: industrial enterprise data and foreign trade data. Industrial enterprise data are based on regular statistical reports and financial statements of enterprises and we obtained them from the Czech Statistical Office. Enterprises with 20 and more employees for legal unit and both incorporated and unincorporated natural persons are included into the database. Trade data were obtained from the Ministry of Industry and Trade and were aggregated on 3 digit level. The data have been gathered on the micro-level on the basis of the custom statistics which were collected by the Directorate General of Customs. We use data for 102 manufacturing industries (3-digit NACE codes from 151 till 372) in the Czech Republic during the period of $1998-2002$. The analysis of the 3-digit NACE aggregated industry data allows us to avoid a problem of unbalanced panel data that often is present when we work with an enterprise level data. Especially it poses a serious problem in transition economies during restructuring from the centrally planned toward market economy. This transition period is characterized by a large number of green field investment and spin-off firms that are entering the market and firms exiting from the market through bankruptcy.

We calculated the $\mathrm{HHI}$ based on the volume of sales of enterprises which belong to a 3-digit NACE industry taken from the Czech Statistical Office dataset. There are several caveats related to the data: According to the Czech Statistical Office a firm belongs to a 3-digit industry if the largest share of its revenue comes from the sale of products classified within that industry. The shortcoming of this methodology is that firms can switch industries over time, because the relative shares of different products in total revenue may change due to market condition, new strategies, and other factors. Further problem is related to the linking of trade and industrial statistics. For computation of import penetration we subtracted direct exports taken from the industrial statistics and added imports taken from the trade statistics into the domestic supply. The import penetration ratio is the share of import in domestic sales [import penetration $=$ imports/(domestic production - exports + imports)]. Such method omits exported goods via wholesale, however, it works better than trade exports that lead to negative values of many industries on 3-digit NACE level. 
Foreign direct investment is captured through foreign ownership of enterprises. As explained above our analysis draws on corporate financial statements submitted to the Czech Statistical Office (CSO), covering the total population of manufacturing enterprises with more than 20 employees. To begin with, we aggregated monthly or quarterly data of individual enterprises to get annual observations, and performed controls for data consistency. Then the enterprises, which can be identified by type of ownership, $\left.{ }^{6}\right)$ were broken down into two groups: foreign-owned enterprises and domestically owned enterprises. Then the FDI penetration ratio was calculated as the share of foreign owned enterprises in the $i$-th industry total sales.

Labour is measured by the number of employees in an industry and capital is measured by the industry-wide volume of current assets. Current assets consist of the sum of receivables and inventories owned by firms in an industry. Given the lack of industry-wide total assets in our dataset we think that it is the best way to represent the size of the industry in terms of capital. These data were obtained from the Czech Statistical Office. We made every effort to ensure data comparability regarding methodology changes made in statistical recording during the review period and at the same time to provide for a broad coverage of data. While the data presented in the article and used for the analysis result from careful adaptation of the CSO data they are not fully comparable with the officially published figures as they reflect own computations. In Table 1 and 2 there is a short description of the data. Table 1 provides some summary statistics for the variables used in the analysis. Table 2 shows the pairwise correlations between the variables used in our analysis.

Table 1

Summary Statistics

\begin{tabular}{|l|c|c|c|c|c|}
\hline Variable & Obs. & Mean & Std. Dev. & Min. & Max. \\
\hline In sales & 502 & 15.1425 & 1.5799 & 8.5757 & 18.6030 \\
In $L$ & 502 & 8.3197 & 1.3470 & 4.0662 & 10.7955 \\
In $K$ & 502 & 12.8645 & 1.5861 & 6.2916 & 16.2056 \\
$(\text { In } K \text {-In } L)^{\wedge} 2$ & 502 & 21.3555 & 7.3388 & 0.7773 & 53.4973 \\
trend & 510 & 3 & 1.4156 & 1 & 5 \\
HHI & 510 & 0.1993 & 0.2189 & 0.0115 & 1 \\
HHI2 & 510 & 0.0875 & 0.1912 & 0.0001 & 1 \\
trend*HHI & 510 & 0.5831 & 0.7590 & 0.0214 & 5 \\
Import Penetration & 464 & 0.6933 & 0.2460 & 0.0864 & 0.99999 \\
FDI & 423 & 0.4786 & 0.2829 & 0.0064 & 1 \\
\hline
\end{tabular}

Source: Data CSO, own computations.

6)The CSO distinguishes the following types of ownership: private, cooperative, state, foreign (100 per cent), international (any 1-99 per cent of foreign ownership), mixed (state and private), others (communal, political organizations and associations or not-identified). For the purpose of this analysis the two groups of foreign firms (fully and partially owned) were merged into one group and the rest into a second group of domestic enterprise. 
Table 2

Pairwise Correlation Coefficients between the Variables

\begin{tabular}{|c|c|c|c|c|c|c|c|c|c|c|}
\hline & In sales & $\ln L$ & $\ln K$ & $(\ln K-\ln L)^{\wedge} 2$ & trend & $H H I$ & $H H \|^{\wedge} 2$ & trend $d^{*} H H I$ & Import pen. & $F D I$ \\
\hline In sales & 1 & & & & & & & & & \\
\hline $\ln \mathrm{L}$ & $\begin{array}{l}0.8957^{\star} \\
0.0000\end{array}$ & 1 & & & & & & & & \\
\hline $\ln \mathrm{K}$ & $\begin{array}{l}0.8585^{*} \\
0.0000\end{array}$ & $\begin{array}{l}0.8491^{*} \\
0.0000\end{array}$ & 1 & & & & & & & \\
\hline$(\ln K-\ln L)^{\wedge} 2$ & $\begin{array}{l}0.1675^{*} \\
0.0002\end{array}$ & $\begin{array}{c}-0.0468 \\
0.2949\end{array}$ & $\begin{array}{l}0.4760^{\star} \\
0.0000\end{array}$ & 1 & & & & & & \\
\hline trend & $\begin{array}{l}0.1015^{\star} \\
0.0229\end{array}$ & $\begin{array}{l}0.0062 \\
0.8899\end{array}$ & $\begin{array}{c}-0.0349 \\
0.4359\end{array}$ & $\begin{array}{l}-0.073 \\
0.1025\end{array}$ & 1 & & & & & \\
\hline$H H I$ & $\begin{array}{c}-0.2280^{*} \\
0.0000\end{array}$ & $\begin{array}{c}-0.4613^{*} \\
0.0000\end{array}$ & $\begin{array}{c}-0.3719^{*} \\
0.0000\end{array}$ & $\begin{array}{l}0.1167^{\star} \\
0.0089\end{array}$ & $\begin{array}{c}-0.0477 \\
0.2825\end{array}$ & 1 & & & & \\
\hline$H H^{\wedge} 2$ & $\begin{array}{c}-0.1559^{*} \\
0.0005\end{array}$ & $\begin{array}{c}-0.3721^{*} \\
0.0000\end{array}$ & $\begin{array}{c}-0.3094^{*} \\
0.0000\end{array}$ & $\begin{array}{l}0.0948^{*} \\
0.0336\end{array}$ & $\begin{array}{c}-0.0389 \\
0.3801\end{array}$ & $\begin{array}{c}0.9495^{\star} \\
0.0000\end{array}$ & 1 & & & \\
\hline trend $^{*} H H I$ & $\begin{array}{c}-0.1236^{*} \\
0.0055\end{array}$ & $\begin{array}{c}-0.3712^{*} \\
0.0000\end{array}$ & $\begin{array}{r}-0.3414^{*} \\
0.0000\end{array}$ & $\begin{array}{l}0.0334 \\
0.4559\end{array}$ & $\begin{array}{l}0.3477^{\star} \\
0.0000\end{array}$ & $\begin{array}{c}0.8193^{*} \\
0.0000\end{array}$ & $\begin{array}{l}0.7686^{\star} \\
0.0000\end{array}$ & 1 & & \\
\hline Import pen. & $\begin{array}{c}-0.4404^{*} \\
0.0000\end{array}$ & $\begin{array}{c}-0.3075^{\star} \\
0.0000\end{array}$ & $\begin{array}{c}-0.4104^{*} \\
0.0000\end{array}$ & $\begin{array}{c}-0.3216^{*} \\
0.0000\end{array}$ & $\begin{array}{c}0.0715 \\
0.124\end{array}$ & $\begin{array}{c}0.019 \\
0.6827\end{array}$ & $\begin{array}{c}-0.0359 \\
0.4407\end{array}$ & 0.4556 & 1 & \\
\hline FDI & $\begin{array}{l}0.0413 \\
0.3967\end{array}$ & $\begin{array}{c}-0.1996^{*} \\
0.0000\end{array}$ & $\begin{array}{c}-0.2167^{\star} \\
0.0000\end{array}$ & $\begin{array}{l}-0.0658 \\
0.1765\end{array}$ & $\begin{array}{l}0.2360^{*} \\
0.0000\end{array}$ & $\begin{array}{l}0.4539^{*} \\
0.0000\end{array}$ & $\begin{array}{l}0.4258^{*} \\
0.0000\end{array}$ & $\begin{array}{l}0.4668^{*} \\
0.0000\end{array}$ & $\begin{array}{l}0.0537 \\
0.2883\end{array}$ & 1 \\
\hline
\end{tabular}

Note: * significant at $5 \% ; P$-values under the estimates.

Source: Data CSO, own computations.

\section{Results}

The initial analysis of the data indicates that the median $\mathrm{HHI}$ in Czech manufacturing is decreasing over the time from 1,368 in 1998 to 979 in 2002. The average value of the $\mathrm{HHI}$ also decreased from 2,303 to 1,957 over the same period, which is a significant drop in industry concentration over the 5-year period (see Figure 1). During the same period of time import and FDI penetrations in the Czech manufacturing increased significantly. Median import penetration increased in the Czech manufacturing from 69.8 per cent as by 1998 to 78.8 per cent in 2002 (Figure 2), and median FDI penetration ratio increased from 16.7 per cent to 51.1 per cent over the period (Figure 3). These facts indicate an increase in both, external and internal, competition pressures on Czech manufacturers during the analyzed period of time.

Having a panel of 102 industries over the 5 years period, we expect that the fixed effect model is a better framework to work in. To check this we run the Hausman test to determine whether the fixed or random effect model is appropriate in our case. ${ }^{7)}$ Inclusion of fixed effects would help us to incorporate and control for

7) Hausman test is a specification test which checks a more efficient model against a less efficient but consistent model to make sure that the more efficient model also gives consistent results (see Hausman, 1978). In other words, the test compares two estimators that are consistent under the null hypothesis. Pooled regression is more efficient than fixed effects regression under the null; while under the alternative, only fixed effects regression is consistent. 
Figure 1

Median and Average Herfindahl-Hirschman Index in the Czech Manufacturing $(1998-2002)$

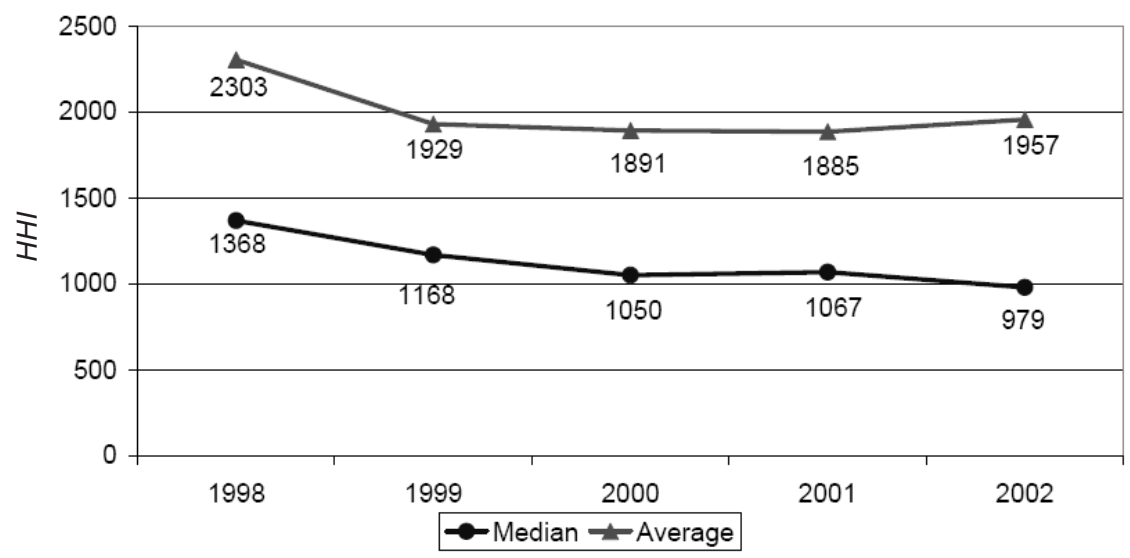

Source: Data CSO, own computations.

Figure 2

Median and Average Import Penetration Ratio in the Czech Manufacturing $(1998$ - 2002)

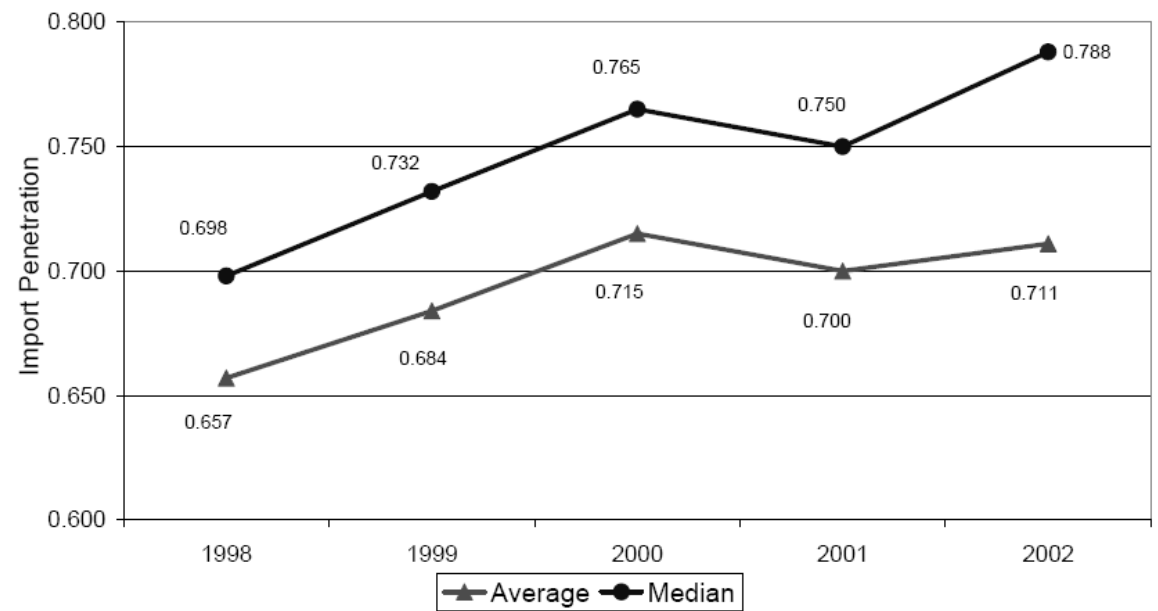

Source: Data CSO, own computations.

unobservable industrial heterogeneity. ${ }^{8)}$ It appears that for all specifications of the model the Hausman test rejects random effect model in favour of fixed effect model, therefore we report only results for the OLS and fixed effect models. ${ }^{9)}$

8) For the importance of fixed effects in panel data analysis see Ashenfelter (1978), Ben-Porath (1973), Hsiao (1985), Hoch (1962), Griliches and Hausman (1986).

9) However, we would like to mention that for all regressions that we present in the paper, coefficients of the random effect model are also significant and have the expected signs. 
Figure 3

Median and Average FDI Penetration Ratio in the Czech Manufacturing (1998 - 2002)

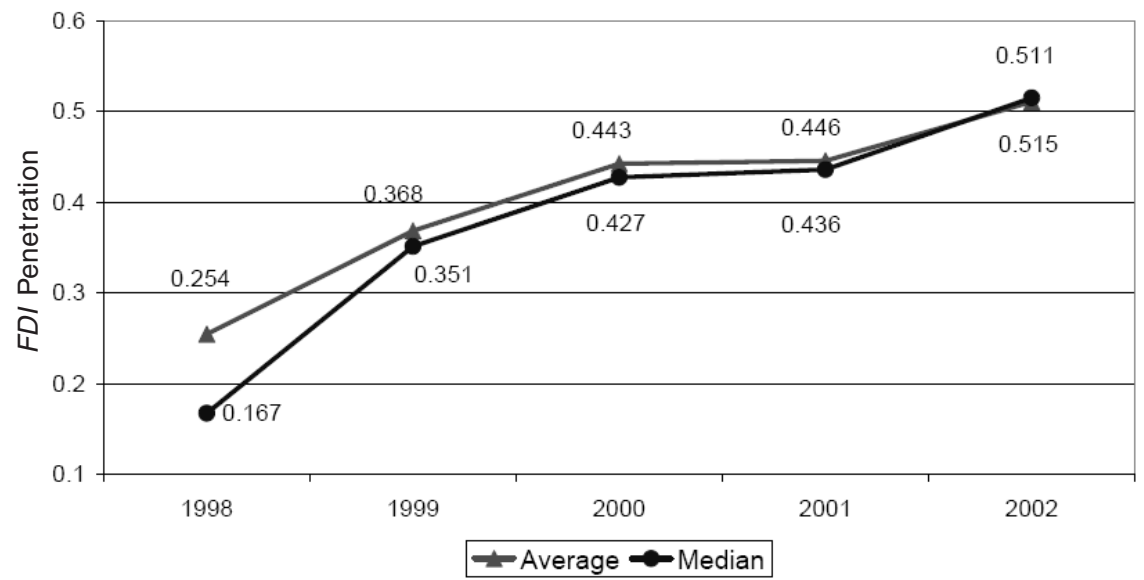

Source: Data CSO, own computations.

Table 3

Dependent Variables: In Sales

\begin{tabular}{|c|c|c|c|c|c|c|c|c|c|c|}
\hline & $\begin{array}{c}1 \\
\text { OLS }\end{array}$ & $\begin{array}{c}2 \\
F E\end{array}$ & $\begin{array}{c}3 \\
O L S\end{array}$ & $\begin{array}{c}4 \\
F E\end{array}$ & $\begin{array}{c}5 \\
O L S\end{array}$ & $\begin{array}{c}6 \\
F E\end{array}$ & $\begin{array}{c}7 \\
O L S\end{array}$ & $\begin{array}{c}8 \\
F E\end{array}$ & $\begin{array}{c}9 \\
O L S\end{array}$ & $\begin{array}{l}10 \\
F E\end{array}$ \\
\hline $\ln L$ & $\begin{array}{c}0.7563^{\star * *} \\
{[0.0450]}\end{array}$ & $\begin{array}{c}1.1079^{* * *} \\
{[0.0511]}\end{array}$ & $\begin{array}{c}0.8298^{* * *} \\
{[0.0508]}\end{array}$ & $\begin{array}{c}0.9626^{* * *} \\
{[0.0507]}\end{array}$ & $\begin{array}{c}0.8644^{* * *} \\
{[0.0476]}\end{array}$ & $\begin{array}{l}1.0046^{\star * *} \\
{[0.0545]}\end{array}$ & $\begin{array}{c}0.7493^{* * *} \\
{[0.0445]}\end{array}$ & $\begin{array}{c}1.0987^{\star \star *} \\
{[0.0512]}\end{array}$ & $\begin{array}{l}1.9046^{* * *} \\
{[0.2245]}\end{array}$ & $\begin{array}{c}1.2510^{* * *} \\
{[0.1442]}\end{array}$ \\
\hline $\ln K$ & $\begin{array}{l}0.3247^{\star * *} \\
{[0.0365]}\end{array}$ & $\begin{array}{c}0.0703^{* * *} \\
{[0.0203]}\end{array}$ & $\begin{array}{c}0.3500^{\star \star *} \\
{[0.0439]}\end{array}$ & $\begin{array}{c}0.1207^{\star * *} \\
{[0.0223]}\end{array}$ & $\begin{array}{c}0.2797^{\star * *} \\
{[0.0422]}\end{array}$ & $\begin{array}{c}0.0634^{* * *} \\
{[0.0218]}\end{array}$ & $\begin{array}{c}0.3285^{\star \star \star} \\
{[0.0366]}\end{array}$ & $\begin{array}{c}0.0741^{\star \star *} \\
{[0.0203]}\end{array}$ & $\begin{array}{c}-0.8148^{\star * *} \\
{[0.2180]}\end{array}$ & $\begin{array}{c}-0.079 \\
{[0.1422]}\end{array}$ \\
\hline trend & $\begin{array}{l}0.0949^{\star * *} \\
{[0.0155]}\end{array}$ & $\begin{array}{l}0.1023^{* * *} \\
{[0.0075]}\end{array}$ & $\begin{array}{c}0.1392^{* * *} \\
{[0.0174]}\end{array}$ & $\begin{array}{l}0.1166^{* * *} \\
{[0.0075]}\end{array}$ & $\begin{array}{c}0.1484^{\star * *} \\
{[0.0172]}\end{array}$ & $\begin{array}{c}0.1234^{* * *} \\
{[0.0075]}\end{array}$ & $\begin{array}{l}0.0584^{\star \star *} \\
{[0.0198]}\end{array}$ & $\begin{array}{c}0.0920^{\star * *} \\
{[0.0095]}\end{array}$ & $\begin{array}{l}0.0921^{* * *} \\
{[0.0150]}\end{array}$ & $\begin{array}{l}0.1031^{* * *} \\
{[0.0075]}\end{array}$ \\
\hline $\mathrm{HHI}$ & $\begin{array}{c}2.4487^{* * *} \\
{[0.4798]}\end{array}$ & $\begin{array}{c}3.0482^{* * *} \\
{[0.3700]}\end{array}$ & $\begin{array}{c}1.8885^{\star * *} \\
{[0.4260]}\end{array}$ & $\begin{array}{c}2.9353^{* * *} \\
{[0.4143]}\end{array}$ & $\begin{array}{c}2.2540^{* * *} \\
{[0.4276]}\end{array}$ & $\begin{array}{c}2.9497^{\star * *} \\
{[0.4246]}\end{array}$ & $\begin{array}{l}1.5949^{* * *} \\
{[0.6036]}\end{array}$ & $\begin{array}{c}2.7828^{\star * *} \\
{[0.3992]}\end{array}$ & $\begin{array}{c}2.1361^{* * *} \\
{[0.4425]}\end{array}$ & $\begin{array}{c}3.0347^{* * *} \\
{[0.3702]}\end{array}$ \\
\hline$H H^{\wedge} 2$ & $\begin{array}{l}-1.0396 \\
{[0.6414]}\end{array}$ & $\begin{array}{c}-1.8954^{\star * *} \\
{[0.3293]}\end{array}$ & $\begin{array}{c}-0.1985 \\
{[0.5092]}\end{array}$ & $\begin{array}{c}-1.9213^{* * *} \\
{[0.3699]}\end{array}$ & $\begin{array}{c}-0.6093 \\
{[0.4668]}\end{array}$ & $\begin{array}{c}-1.7919^{* * *} \\
{[0.3863]}\end{array}$ & $\begin{array}{c}-0.8067 \\
{[0.5699]}\end{array}$ & $\begin{array}{c}-1.7446^{* * *} \\
{[0.3394]}\end{array}$ & $\begin{array}{c}-0.913 \\
{[0.5632]}\end{array}$ & $\begin{array}{c}-1.8567^{* * *} \\
{[0.3312]}\end{array}$ \\
\hline $\begin{array}{l}\text { Import } \\
\text { penetration }\end{array}$ & $\begin{array}{c}-0.7455^{\star * *} \\
{[0.1002]}\end{array}$ & $\begin{array}{c}-0.7809^{\star * *} \\
{[0.2140]}\end{array}$ & & & $\begin{array}{c}-0.7617^{* * *} \\
{[0.1083]}\end{array}$ & $\begin{array}{c}-0.5862^{* * *} \\
{[0.2122]}\end{array}$ & $\begin{array}{c}-0.7244^{* * *} \\
{[0.1025]}\end{array}$ & $\begin{array}{c}-0.7477^{\star * *} \\
{[0.2141]}\end{array}$ & $\begin{array}{c}-0.6798^{* * *} \\
{[0.0988]}\end{array}$ & $\begin{array}{c}-0.7737^{\star * *} \\
{[0.2140]}\end{array}$ \\
\hline FDI & $\begin{array}{c}0.5794^{* * *} \\
{[0.0888]}\end{array}$ & $\begin{array}{l}0.4206^{* * *} \\
{[0.0743]}\end{array}$ & & & & & $\begin{array}{l}0.5849^{* * *} \\
{[0.0914]}\end{array}$ & $\begin{array}{c}0.4279^{\star * *} \\
{[0.0741]}\end{array}$ & $\begin{array}{c}0.5786^{* * *} \\
{[0.0858]}\end{array}$ & $\begin{array}{c}0.4097^{\star * *} \\
{[0.0750]}\end{array}$ \\
\hline trend ${ }^{*} H H I$ & & & & & & & $\begin{array}{c}0.2240^{*} \\
{[0.1206]}\end{array}$ & $\begin{array}{l}0.0620^{*} \\
{[0.0357]}\end{array}$ & & \\
\hline$(\ln L-\ln K)^{\wedge} 2$ & & & & & & & & & $\begin{array}{l}0.1314^{* * *} \\
{[0.0246]}\end{array}$ & $\begin{array}{c}0.0182 \\
{[0.0172]}\end{array}$ \\
\hline Constant & $\begin{array}{c}4.3207^{* * *} \\
{[0.2982]}\end{array}$ & $\begin{array}{c}4.6666^{* * *} \\
{[0.4862]}\end{array}$ & $\begin{array}{c}2.9671^{* * *} \\
{[0.2833]}\end{array}$ & $\begin{array}{c}4.8216^{* * *} \\
{[0.3559]}\end{array}$ & $\begin{array}{c}4.0536^{\star * *} \\
{[0.3239]}\end{array}$ & $\begin{array}{c}5.5854^{* * *} \\
{[0.4980]}\end{array}$ & $\begin{array}{c}4.4407^{\star * *} \\
{[0.2862]}\end{array}$ & $\begin{array}{c}4.7062^{* * *} \\
{[0.4851]}\end{array}$ & $\begin{array}{c}6.6412^{* * *} \\
{[0.4967]}\end{array}$ & $\begin{array}{c}5.0098^{* * *} \\
{[0.5840]}\end{array}$ \\
\hline Observations & 393 & 393 & 502 & 502 & 464 & 464 & 393 & 393 & 393 & 393 \\
\hline$R$-squared & 0.91 & 0.83 & 0.89 & 0.71 & 0.9 & 0.74 & 0.91 & 0.83 & 0.91 & 0.83 \\
\hline $\begin{array}{l}\text { Number } \\
\text { of nace }\end{array}$ & & 84 & & 102 & & 94 & & 84 & & 84 \\
\hline
\end{tabular}

Source: Data CSO, own computations.

Robust standard errors in brackets

* significant at $10 \%$, ${ }^{* \star}$ significant at $5 \%$, ${ }^{* \star *}$ significant at $1 \%$ 
The results of estimations are presented in Table 3 . We find a significant relationship between competition and performance, and the coefficients of interest stay significant, preserve the same signs and do not differ much under different specifications of the model. Under all specifications of the model the coefficient in front of the $\mathrm{HHI}$ is significant as well as the coefficient in front of the squared $\mathrm{HHI}$. The coefficient in front of the $\mathrm{HHI}$ is positive, but negative in front of the squared term. ${ }^{10}$ ) The data show that there is an increasing but diminishing return of the industry-wide performance on the level of concentration in the Czech manufacturing sector, i.e. the more concentrated industry, the higher the level of performance. However, we cannot claim the causality between competition and performance, but we can only claim that there is a significant relationship between the level of concentration and performance of industries in the Czech Republic during the 5 years period.

The trend variable picks up the effect of growth in all industries through the time. In our analysis the trend variable is positive and significant across all specifications. It could be explained by the movement of the Czech manufacturing, and the economy in general, toward the production and technological frontier. In one of the specifications of the model (see Table 3, column 8) we include an interaction term between trend and the HHI. The coefficient in front is positive and significant at $10 \%$ significance, which indicates that the more concentrated the industry, the higher the total factor productivity (i.e. more concentrated industries are growing faster with time).

The coefficient in front of the import penetration is negative and highly significant under all specifications. That might underline the fact that Czech companies which operate in manufacturing industries are not catching up with their foreign rivals, and the gap is widening. This contradicts the idea (and hope) at the beginning of the transition period that the presence of and competition with foreign companies would make Czech companies more efficient through the technology and skills spillovers.

We could argue that there is a certain number of industries that are not attractive for foreign investors to acquire and to move the production to the Czech Republic and it could be explained by various reasons. Certain markets in the Czech Republic are not big enough to have production facilities in the country and it is much more profitable to keep the production in other countries, say in Germany, and export goods to the Czech Republic so such industries could be described by a high import penetration rate. Another reason could be that the Czech Republic might not possess comparative advantages in some industries and the production facilities are located in neighbouring transition countries as Poland, Slovakia, or Hungary. In this case again the products of these industries will be imported to the Czech Republic.

As it was expected and well documented in the literature on transition economies the industries with high share of foreign direct investment are performing significantly better than domestic ones. The coefficient in front of FDI is positive and significant under all specifications of the model. This could be explained by the inside-the-multinational-firms transfer of the up-to-date technology, better access to financial resources and the application of the best managerial practices.

However, we could be suspicious of the quadratic term in our model. The quadratic term is sensitive to extreme observations and the significance of the coefficient in front of quadratic term could be accidental and spurious. Thus we will conduct a robustness check of our non-linearity hypothesis by creating dummies for different level of the $\mathrm{HHI}$ and then run regressions with interaction terms between

10) Later in the section we will conduct a robustness test of the non-linearity of the relationship. 
dummies and $H H I$. It will allow us to estimate the difference in slopes for industries with different concentration levels (for example, with high and low levels of concentration) and to check whether the slope of the line becomes flatter as concentration increases. We can split the sample in many ways but all of them are arbitrary. Here in the paper we present two possible segmentations of industries according to the concentration level. The first segmentation follows the U.S. Department of Justice. According to the Horizontal Merger Guidelines, ${ }^{11)}$ the spectrum of market concentration as measured by the $\mathrm{HHI}$ is divided into three regions that can be broadly characterized as non-concentrated $(\mathrm{HHI}$ below 1,000), moderately concentrated

Table 4

Regression with Dummies for Not Concentrated, Mid-Concentrated, and Highly Concentrated Markets

\begin{tabular}{|c|c|c|}
\hline \multicolumn{3}{|c|}{ Dependent variable: In Sales } \\
\hline & $\begin{array}{c}1 \\
O L S\end{array}$ & $\begin{array}{c}2 \\
F E\end{array}$ \\
\hline $\ln L$ & $\begin{array}{c}0.7480^{* * *} \\
{[0.0442]}\end{array}$ & $\begin{array}{l}1.1449^{* * *} \\
{[0.0533]}\end{array}$ \\
\hline $\ln K$ & $\begin{array}{c}0.3256^{* * *} \\
{[0.0379]}\end{array}$ & $\begin{array}{c}0.0599^{* * *} \\
{[0.0212]}\end{array}$ \\
\hline trend & $\begin{array}{c}0.0954^{* * *} \\
{[0.0156]}\end{array}$ & $\begin{array}{c}0.0979 * * * \\
{[0.0078]}\end{array}$ \\
\hline$H H /$ not & $\begin{array}{c}1.2794 \\
{[0.9805]}\end{array}$ & $\begin{array}{c}1.6039^{* * *} \\
{[0.5694]}\end{array}$ \\
\hline$H H / m i d$ & $\begin{array}{c}1.8643^{\star * *} \\
{[0.5848]}\end{array}$ & $\begin{array}{c}0.8770^{* \star *} \\
{[0.3327]}\end{array}$ \\
\hline$H H /$ high & $\begin{array}{c}1.6287^{* * *} \\
{[0.2359]}\end{array}$ & $\begin{array}{l}1.1048^{* * *} \\
{[0.1672]}\end{array}$ \\
\hline Import penetration & $\begin{array}{c}-0.7300^{* * *} \\
{[0.0942]}\end{array}$ & $\begin{array}{c}-0.9718^{* * *} \\
{[0.2222]}\end{array}$ \\
\hline FDI & $\begin{array}{c}0.5797^{\star * *} \\
{[0.0875]}\end{array}$ & $\begin{array}{c}0.4873^{\star * *} \\
{[0.0769]}\end{array}$ \\
\hline Constant & $\begin{array}{c}4.4432^{* * *} \\
{[0.3370]}\end{array}$ & $\begin{array}{c}4.7909^{* * *} \\
{[0.5103]}\end{array}$ \\
\hline Observations & 393 & 393 \\
\hline$R$-squared & 0.9 & 0.81 \\
\hline Number of nace & & 84 \\
\hline
\end{tabular}

Robust standard errors in brackets

* significant at $10 \%,{ }^{* *}$ significant at $5 \%,{ }^{* * *}$ significant at $1 \%$

Source: Data CSO, own computations.

11) U.S. Department of Justice Horizontal Merger Guidelines:http://www.usdoj.gov/atr/public/guidelines/ hmg.htm. 
Table 5

Regression with Dummies for Low and High Concentrated Industries

\begin{tabular}{|c|c|c|}
\hline \multicolumn{3}{|c|}{ Dependent variable: In Sales } \\
\hline & $\begin{array}{c}1 \\
O L S\end{array}$ & $\begin{array}{c}2 \\
F E\end{array}$ \\
\hline $\ln L$ & $\begin{array}{c}0.7474^{\star * *} \\
{[0.0441]}\end{array}$ & $\begin{array}{l}1.1443^{\star * *} \\
{[0.0533]}\end{array}$ \\
\hline $\ln K$ & $\begin{array}{c}0.3242^{\star * *} \\
{[0.0370]}\end{array}$ & $\begin{array}{c}0.0599^{* * *} \\
{[0.0212]}\end{array}$ \\
\hline trend & $\begin{array}{c}0.0947^{* * *} \\
{[0.0155]}\end{array}$ & $\begin{array}{c}0.0987^{* * *} \\
{[0.0078]}\end{array}$ \\
\hline HHI low & $\begin{array}{c}0.9921 \\
{[0.8411]}\end{array}$ & $\begin{array}{l}1.8962^{\star \star \star} \\
{[0.4694]}\end{array}$ \\
\hline$H H I$ high & $\begin{array}{l}1.6001^{* * *} \\
{[0.2290]}\end{array}$ & $\begin{array}{l}1.1405^{\star \star *} \\
{[0.1625]}\end{array}$ \\
\hline Import penetration & $\begin{array}{c}-0.7264^{\star * *} \\
{[0.0948]}\end{array}$ & $\begin{array}{c}-0.9841^{* * *} \\
{[0.2217]}\end{array}$ \\
\hline$F D I$ & $\begin{array}{c}0.5782^{* * *} \\
{[0.0877]}\end{array}$ & $\begin{array}{c}0.4873^{* * *} \\
{[0.0769]}\end{array}$ \\
\hline Constant & $\begin{array}{c}4.4857^{* * *} \\
{[0.3135]}\end{array}$ & $\begin{array}{c}4.7823^{* * *} \\
{[0.5101]}\end{array}$ \\
\hline Observations & 393 & 393 \\
\hline$R$-squared & 0.9 & 0.81 \\
\hline Number of nace & & 84 \\
\hline
\end{tabular}

Robust standard errors in brackets

${ }^{*}$ significant at $10 \%,{ }^{* *}$ significant at $5 \%,{ }^{* *}$ significant at $1 \%$

Source: Data CSO, own computations.

( $H H I$ between 1,000 and 1,800), and highly concentrated $(H H I$ above 1,800$)$. In the second case we split industries into two segments: non-concentrated $(H H I$ is below $1,000)$ and concentrated $(H H I$ is above 1,000$)$.

We test for significance of the total difference between industries with different level of concentration (none, medium, and high in the first case and concentrated and not concentrated in the second case). We predict that if the non-linear model is valid then the coefficient in front of the interaction term of the non-concentrated industries $(H H I$ is below 1,000) will be positive and greater than the coefficient(s) in front of the term for the concentrated industries (medium and highly concentrated industries).

In Table 4 and 5 we can see the results of the estimations and the support for the non-linear model. The coefficients in front of the interaction terms are significant and there is a change in slope for different levels of concentration. In the case of three different levels of concentration, the value of the coefficient for the non-concentrated industries is 1.6039 , but then it decreases for medium and highly concentrated industries ( 0.877 and 1.1048 , respectively). This decrease shows the increasingly diminishing return of performance to the level of concentration. The same evidence of the non-linearity can be observed in the case of two-segment concen- 
tration with the value of the coefficient 1.8962 for the non-concentrated industries and the decrease in the coefficient value to 1.1405 for the concentrated industries with $\mathrm{HHI}$ above 1,000. Therefore, both checks support the idea of the increasing nonlinear diminishing relationship between the level of concentration and the performance of Czech manufacturing industries.

\section{Conclusion}

Czech manufacturing industries with high concentration performed better than industries with fragmented market structures during $1998-2002$. It could be explained by the effect that Czech economy is a small economy. In many markets firms must reach competitive scales of production, advertising and $R \& D$ in order to be competitive, which requires increasing market concentration. As long as there exist potential competition and no major barriers to entry firms in concentrated markets can be efficient. Schumpeterian theory of creative destruction claims that monopoly profit extracted from the dominant position creates enough financial resources and incentives to innovate, which in turn leads to more efficient production and better performance.

Our analysis finds that industries with high import penetration are declining. It shows that Czech firms did not withstand import competition because numerous Czech markets are too small to have efficient domestic production facilities. At the same time our analysis confirmed that industries with high share of foreign direct investment are the growing industries. However, we cannot claim the causality between competition and performance, but we can only claim that there is a significant relationship between level of concentration and performance of industries as well as between foreign involvement in the Czech economy and performance of industries during the 5 years period.

References

Angelucci, M., Estrin, S., Konings, J., Zolkiewski, Z. (2001), "The Effect of Ownership and Competitive Pressure on Firm Performance in Transition Countries: Micro Evidence from Bulgaria, Romania and Poland." London, CEPR Discussion Paper No. 2985.

Ashenfelter, O. (1978), "Estimating the Effect of Training Programs on Earnings." Review of Economics and Statistics, 60, pp. 47-57.

Ben-Porath, Y. (1973), "Labor-Force Participation Rates and the Supply of Labor." Journal of Political Economy, 81(3), pp. 697-704.

Brown, D., Earle, J. (2000), "Competition and Firm Performance: Lessons from Russia." London, CEPR Discussion Paper No. 2444.

Carlin, W., Fries, S., Schaffer, M., Seabright, P. (2001), "Competition and Enterprise Performance in Transition Economies: Evidence from a Cross-Country Survey." London, EBRD Working Paper No. 63.

Chirmiciu, A. (2003), "Competition and Industrial Performance During Transition: Evidence from Hungary." Cambridge, University of Cambridge, mimeo.

Djankov, S., Murrell, P. (2002), "Enterprise Restructuring in Transition: A Quantative Survey." London, CEPR Discussion Paper No. 3319.

Geroski, P. (1990), "Innovation, Technological Opportunities, and Market Structure." Oxford Economic Papers, 42(3), pp. 586-602.

Griliches, Z., Hausman, J. (1986), "Errors-in-Variables in Panel Data." Journal of Econometrics, 31, pp. 93-118.

Halpern, L., Korosi, G. (2000), "Efficiency and Market Share in Hungarian Corporate Sector." Ann Arbor, Michigan, William Davidson Institute Working Paper No. 333. 
Hanousek, J., Kočenda, E., Švejnar, J. (2004), "Ownership, Control and Corporate Performance after Large-Scale Privatization." Ann Arbor, Michigan, William Davidson Institute Working Paper No. 652. Haskel, J. (1991), "Imperfect Competition, Work Practices and Productivity Growth." Oxford Bulletin of Economics and Statistics, 53(3), pp. 265-280.

Hausman, J. (1978), "Specification Tests in Econometrics." Econometrica, 46(6), pp. 1251-1271.

Havlik, P. (2000), "Structural Change, Trade Specialization and Competitiveness of Manufacturing Industry in Central and Eastern Europe," in Landesmann, M., ed., WIIW Structural Report: Structural Developments in Central and Eastern Europe. Vienna: The Vienna Institute for International Economic Studies (WIIW), pp. 87-120.

Hoch, I. (1962), "Estimation of Production Function Parameters Combining Time-Series and CrossSection Data." Econometrica, 30, pp. 34-53.

Hsiao, C. (1985), "Benefits and Limitations of Panel Data." Econometric Reviews, 4, pp.121-174.

Konings, J., van Cayseele, P., Warzynski, F. (2003), "The Effects of Privatization and International Competitive Pressure on Firms' Price-Cost Margins: Micro Evidence from Emerging Economies." London, CEPR Discussion Paper No. 3703.

Lízal, L. (2001), "Determinants of Financial Distress: What Drives Bankruptcy in a Transition Economy? The Czech Republic Case." Prague, CERGE-EI Discussion Paper No. 2001-68.

Nickell, S. (1996), "Competition and Corporate Performance." Journal of Political Economy, 104(4), pp. 724-746.

Sabrianová, K., Švejnar, J., Terrell, K. (2004), "Foreign Investment, Corporate Ownership, and Development: Are Firms in Emerging Markets Catching up to the World Standard?" Ann Arbor, Michigan, William Davidson Institute Working Paper No.734.

Schmidt, K. (1997), "Managerial Incentives and Product Market Competition." Review of Economic Studies, 64(2), pp. 191-213.

Vining, A., Boardman A. (1992), "Ownership Versus Competition: Efficiency in Public Enterprise." Journal of Public Choice, 73(2), pp. 205-239.

Zemplinerová, A., Stibal, J. (1995), "Evolution and Efficiency of Concentration in Manufacturing." in Švejnar, J. ed., The Czech Republic and Economic Transition in Eastern Europe. New York: Academic Press, pp. 233-254.

Zemplinerová, A. (1998), "Impact of Foreign Direct Investment on the Restructuring and Growth in Manufacturing." Prague Economic Papers, 1998(4), pp. 329-345.

(2000), "Impact of Foreign Trade on Market Concentration: Czech Manufacturing

Industries in 1993 - 1997." Prague Economic Papers, 9(4), pp. 339-353.

www.czso.cz 